\title{
Soils and Fertilizers for Master Gardeners: The Soil Profile and Soil Classification ${ }^{1}$
}

Amy L. Shober ${ }^{2}$

\section{Introduction}

Soils are an important part of the natural landscape. They provide a medium for plant root growth and are important for nutrient cycling and water movement. Soils act as an environmental filter, helping to remove nutrients and pollutants from water before it reaches our lakes, rivers, oceans, or ground water. This publication provides information about the characteristics and classification of soils as found in the landscape under natural conditions.

\section{The Soil Profile}

"A soil" is a three-dimensional natural body comprised of solids, liquid, and gas that occurs on the land surface. The grouping of these three-dimensional soil bodies makes up "the soil" as it exists over the earth's surface. Soils are made up of layers called horizons, which can be seen when a vertical section of the soil is exposed. The properties (e.g., color, texture, fertility) of individual soil horizons vary as a result of physical, chemical and biological processes that led to their formation. As shown in Figure 1, undisturbed (natural) soils will exhibit one or more of the following horizons (in vertical order of appearance from the top of the soil profile downward):

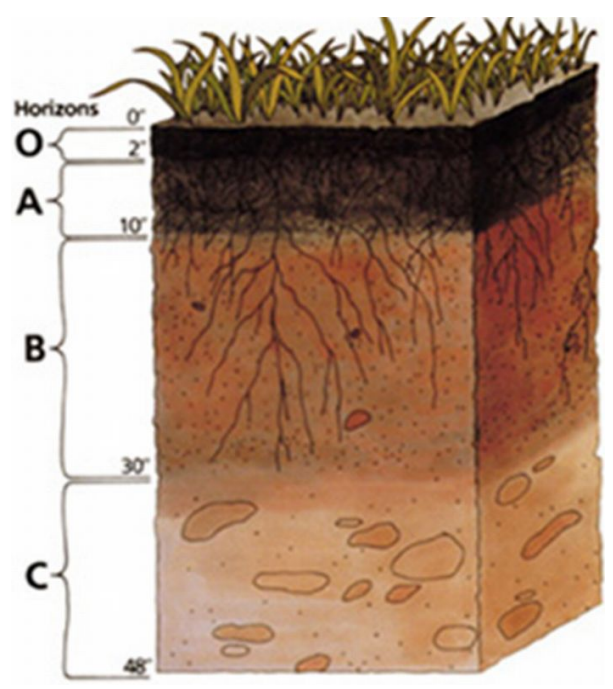

Figure 1. The soil profile.

O Horizon: This consists of the surface accumulation of organic materials (plant or animal residues) in various stages of decomposition. Often, freshly deposited materials are found at the surface of the soil that can be identified as a specific plant or animal material (e.g., pine needles, animal waste). More decomposed materials are often found

1. This document is SL 260, one of a series of the Soil and Water Science Department, Florida Cooperative Extension Service, Institute of Food and Agricultural Sciences, University of Florida. Original publication date June 2008. Visit the EDIS Web Site at http://edis.ifas.ufl.edu.

2. Amy L. Shober, assistant professor, Center for Landscape Conservation and Ecology, Department of Soil and Water Science, Gulf Coast Research and Education Center (REC)-Balm, Florida Cooperative Extension Service, Institute of Food and Agricultural Sciences, University of Florida, Gainesville, FL 32611 .

The Institute of Food and Agricultural Sciences (IFAS) is an Equal Opportunity Institution authorized to provide research, educational information and other services only to individuals and institutions that function with non-discrimination with respect to race, creed, color, religion, age, disability, sex, sexual orientation, marital status, national origin, political opinions or affiliations. U.S. Department of Agriculture, Cooperative Extension Service, University of Florida, IFAS, Florida A. \& M. University Cooperative Extension Program, and Boards of County Commissioners Cooperating. Larry Arrington, Dean 
underneath the freshly deposited materials. These decomposed materials are often no longer distinguishable as specific residues; rather, they appear to be rich, dark colored material.

A Horizon: This is a surface soil horizon consisting of mineral soil material that has been enriched with organic material. As a result, the A horizon is often dark in color. This horizon is often referred to as the topsoil and usually consists of the most fertile soil.

E Horizon: Just below the A horizon, there may be a relatively light colored soil horizon dominated by mineral materials. Organic matter and/or clay and iron have been moved downward by water and removed from this horizon. The E horizon is common in soils formed under pine forest vegetation and often looks similar to sandbox sand.

B Horizon: This horizon is characterized by an accumulation of organic matter, clay or other minerals that have been transported from surface horizons or formed in place as a result of soil chemical and physical processes. Soil in this horizon is often referred to as subsoil.

C Horizon: This horizon is the least developed of the soil horizons and often represents the material from which the soil was formed. Soil in the $\mathrm{C}$ horizon has been impacted to a small extent by chemical and physical forces. Soil in this horizon is also part of the subsoil.

R Horizon: This horizon consists of bedrock material. This material, if found, is usually the material from which the soil formed as a result of physical and chemical breakdown. However, if bedrock is found in a Florida soil, it does not often represent the "parent material" of the soil above it. Florida bedrock is a remnant of marine origin; the sandy material above was deposited on top of the rock through a sedimentation process caused by rising and falling sea level over thousands of years.

\section{A Basic Overview of Soil Classification}

Just like animals, plants and insects, soils are classified based on soil physical, chemical, and biological properties as observed in the landscape. The classification system used for soils is called soil taxonomy. Soil taxonomy is a hierarchical system, with six categories. The soil order is the broadest category of classification used to describe soils. Soils are assigned to an order based on the presence or absence of specific soil properties in surface or subsurface horizons. There are 12 distinct soil orders located throughout the world, seven of which are found in Florida. (For more information on the soil orders in Florida, see the EDIS publication Key to Soil Orders in FL http://edis.ifas.ufl.edu/SS113).

Within the soil orders, soils are grouped into smaller categories called suborders, followed by great groups, subgroups, families, and series. The most specific categorization unit is the soil series. Soils within a series are characterized by a similar arrangement of soil horizons with consistent physical, chemical and biological properties. Soil series are usually named after the geographic location where they were first described or a nearby geographic feature (e.g., Bradenton, Immokalee). The Myakka soil series, its name originating from a Native American term for "big waters", is Florida's official state soil (Figure 2). Soil series descriptions are available on the web at: http://soils.usda.gov/technical/classification/osd/ index.html.

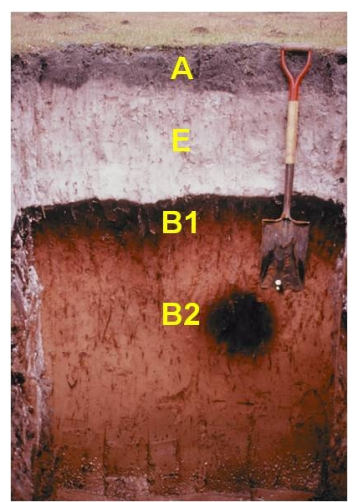

Figure 2. The soil profile of the Myakka soil series.

The Soil Survey

Soil scientists from the United States Department of Agriculture - Natural Resources Conservation Service (USDA-NRCS) have been mapping and classifying soils for many years. They have assembled important information about soils, 
including soil descriptions and classifications into the soil survey. The soil survey also includes information about the suitability of soils for different uses (e.g., building, recreation, agriculture, roadways, septic systems, etc.). Soil surveys used to be published as a hard copy book; however, the most up-to-date soil survey information is now available via the internet at http://websoilsurvey.nrcs.usda.gov/app/. For more information about soil surveys, see the EDIS publication The Nature and Use of a Soil Survey (http://edis.ifas.ufl.edu/SS160).

\section{Summary}

In their natural state, soils are made up of layers called horizons. The properties of each individual horizon, as well as the presence or absence of a specific soil horizon depend on the physical, chemical and biological processes that occurred during the formation of the soil. Soils are classified by as system called soil taxonomy, based on the properties of soil horizons. Information about the classification and suitability of regionally important soils can be found in the soil survey.

\section{References}

N.C. and Weil, R.R. 2002. The Nature and Properties of Soil. 13th ed. Prentice hall, Upper Saddle River, NJ. 